International Journal of Social Sciences and Humanities
Available online at www.sciencescholar.us
Vol. 5 No. 3, December 2021, pages: 176-183
e-ISSN: 2550-7001, p-ISSN: 2550-701X
https://doi.org/10.53730/ijssh.v5n3.1580

\title{
Local Government's Response to the Recovery of the Tourism Sector After the COVID-19 Pandemic: Case Study in Singkawang City, Indonesia
}

\begin{abstract}
( ) CrossMark
Martoyo ${ }^{\text {a }}$, Herlan ${ }^{\mathrm{b}}$, Nahot Tua Parlindungan Sihaloho ${ }^{\mathrm{c}}$, Deni Darmawan ${ }^{\mathrm{d}}$

Manuscript submitted: 27 August 2021, Manuscript revised: 18 September 2021, Accepted for publication: 09 October 2021

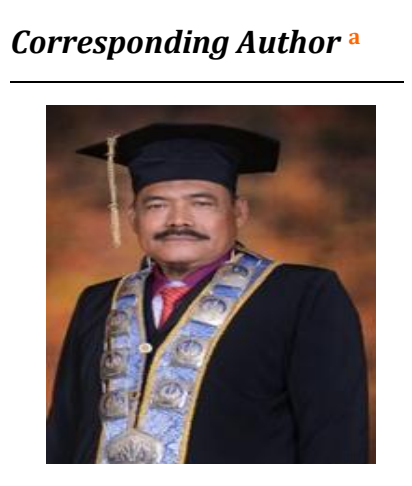

Keywords

coronavirus;

government strategy;

policy implementation;

public policy;

tourism policy;

\section{Abstract}

This study aims to analyze the strategy of the Singkawang City Government in restoring the private sector during the COVID-19 pandemic. The research method is descriptive and qualitative, specifically related to the COVID-19 impact mitigation strategy and Singkawang tourism policies. Then analyze the strategic elements of a policy according to the implementation of the 0.Jones model. Data was collected by using interviews, observation, and documentation techniques. The data is then analyzed using domain data analysis techniques as a researcher's effort to get a general and comprehensive (holistic) picture of the object under study. The findings in this study are 1) a connected tourism COVID-19 impact mitigation policy strategy from the national to local levels in Singkawang in the form of directives, regulations, COVID-19 mitigation programs, and stimulus for economic recovery in the tourism sector; and 2) there are no visible creative efforts based on health protocols in organizing tourism resources, methods, and unit synergies to restore tourism, interpretation of social media-based policies regarding tourist visits has not been measured, and strategies have not been implemented to meet the opportunities for pandemic trend tourism types with models alternative tourism according to health protocols.
\end{abstract}

International Journal of Social Sciences and Humanities (C) 2021. This is an open access article under the CC BY-NC-ND license (https://creativecommons.org/licenses/by-nc-nd/4.0/).

\section{Contents}

Abstract

1 Introduction.

${ }^{a}$ University of Tanjungpura, Pontianak, Indonesia

${ }^{\text {b }}$ University of Tanjungpura, Pontianak, Indonesia

c University of Tanjungpura, Pontianak, Indonesia

${ }^{\text {d }}$ University of Tanjungpura, Pontianak, Indonesia 


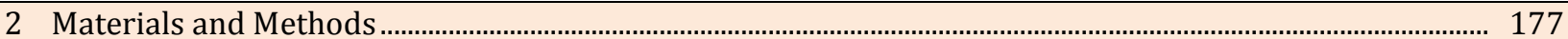

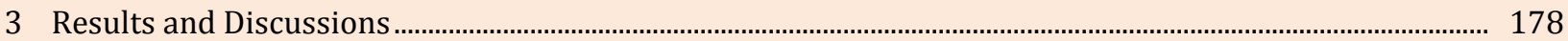

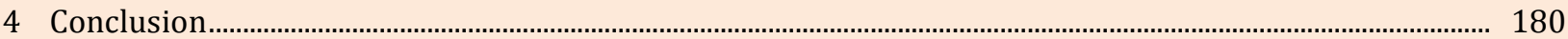

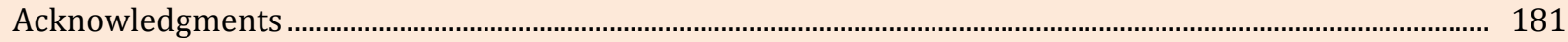

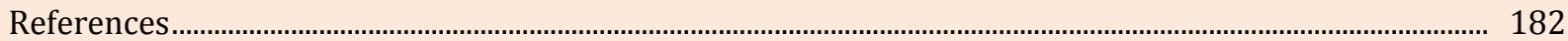

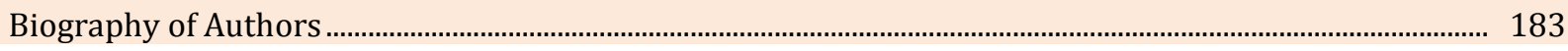

\section{Introduction}

Singkawang City Tourism is a national tourism destination (DPN) in West Kalimantan, Indonesia, affected by the COVID-19 pandemic. West Kalimantan, which ranks 19th province affected by the coronavirus with 50 cases on April 24, 2020 (dinkes.kalbarprov.go.id, 2020), is allegedly experiencing a decline in tourism conditions. The Cap Go Meh Chinese cultural event, usually crowded in Singkawang, has declined in 2020. Information from the Indonesian Hotel and Restaurant Association of West Kalimantan Province, as reported by kompas.com media, by Yuliardi Kamal, stated that there was a decline in the number of foreign tourists and local tourists who came to West Kalimantan related to the Cap Go Meh cultural event (kompas.com, 2021).

Since the coronavirus outbreak, several foreign tourists have canceled trips and hotels, especially in Pontianak and Singkawang City. However, according to the Chairman of the Indonesian Hotel and Restaurant Association, West Kalimantan Province, as reported by kompas.com, the flight restriction policy was deemed appropriate. The government is obliged to protect its citizens so that they are safe from COVID-19. Currently, the number of tourists is reduced so that the hotel occupancy rate also drops. Hotel occupancy rates in Singkawang, which are usually full of tourists ahead of Cap Go Meh, according to the Chairman of the Indonesian Hotel and Restaurant Association (PHRI) West Kalimantan, in 2020, hotel occupancy rates fell by 50 percent compared to the previous Cap Go Meh celebration. Some travel agency owners also complained about the number of trip cancellations to Singkawang City (González-Torres et al., 2021; Haque, 2015).

The challenges of tourism during the COVID-19 pandemic certainly add to the burden of implementing tourism policies in standard times. Tourism policy in regular times is not optimally implemented if it relies on applicable laws and regulations such as Law 10/2009 concerning Tourism, PP 50/2011 concerning the Master Plan for National Tourism Development 2010-2025, Singkawang City Regulation Number 6 of 2013 concerning Tourism Implementation (singkawangkota.go.id, 2021). The problem is limited to the Singkawang City tourism policy strategy in mitigating the impact of COVID-19, the economic recovery of the tourism sector, and the activities of the Department of Tourism, Youth and Sports (Disparpora) Singkawang City in organizing, interpreting, and applying its policies, in particular answering the problem formulation on how the strategy and implementation of Singkawang City tourism policies face the impact of the COVID-19 pandemic?

\section{Materials and Methods}

The research method is descriptive research with a qualitative approach. Researchers have implemented scientific and systematic efforts to explain the tourism phenomenon of Singkawang City in dealing with the impact of the COVID-19 pandemic through mitigation policy strategies, economic recovery in the tourism sector, and implementation of organizing, interpreting, and applying activities by the Singkawang Tourism, Youth and Sports Office. The place or location of the research was carried out in Singkawang City, with the following logical reasons:

1) Singkawang City is one of the leading National Tourism Destinations (DPN) in West Kalimantan

2) The impact of the COVID-19 pandemic had occurred since the Cap Go Meh event before the coronavirus was confirmed to have entered Indonesia.

3) The Department of Tourism, Youth and Sports are directly responsible for organizing tourism in Singkawang destinations.

Martoyo, M., Herlan, H., Sihaloho, N. T. P., \& Darmawan, D. (2021). Local government's response to the recovery of the tourism sector after the COVID-19 pandemic: case study in Singkawang City, Indonesia. International Journal of Social Sciences and Humanities, 5(3), 176-183. https://doi.org/10.53730/ijssh.v5n3.1580 
Subjects in this study were taken purposively and incidentally, consisting of 1) Key Informants. Namely, those who have the knowledge and have the preliminary information needed, such as officials in the Singkawang City Government; 2) Main informants, namely ASN in charge of tourism marketing at the Department of Tourism, Youth and Sports; 3) Additional Informants namely those who directly experience the implementation of the policy. In this study, the research team used additional informants, namely netizen participants, who were asked for online information. This study also uses random sampling to determine participants through area/regional sampling (Sugiyono, 2015). The object of research is the Department of Tourism, Youth and Sports Strategy in tackling the impact of COVID-19 on tourism in Singkawang City.

According to Woll, public policy is several government activities to solve problems in society, either directly or through various institutions that affect people's lives (Woll, 2002). Similarly, Chandler (1982), argue that public policies existing resources to solve public or government problems. Easton (1979), defines public policy as "the authoritative allocation of values for the whole society." This definition means the authoritative allocation of values for society shows that only the government can legally do something to its citizens as the authorized owner.

\section{Results and Discussions}

The government's choice to do something or not to do something is realized by placing values, such as the government's action in implementing Large-Scale Social Restrictions (PSBB), in several areas in the context of accelerating the handling of COVID-19. The government does this legally by issuing Government Regulation No. 21 of 2020, which among other things, provides the value of community discipline to reduce activities outside the home, wear masks, maintain distance, avoid crowds, etc. Several social sanctions and fines have also been applied to violators-large-Scale Social Restrictions (PSBB).

This is because the government is included in the "authorities in a political system," namely the ruling party in a political system order who is involved in the routine affairs of the political system and has specific responsibilities where they are asked to make decisions at a time. Later, the decision is accepted and binds the community for a certain period. Such as implementing health protocols according to the Circular Letter of the Minister of Health of the Republic of Indonesia Number HK.02.01/Menkes/199/2020 and the COVID-19 Prevention and Control Guidelines released by the Director-General of Disease Prevention and Control, in every activity of the community, business, and government (Škare et al., 2021; Amerta et al., 2018).

Based on the expert's perspective, it is concluded that public policies related to Singkawang tourism in dealing with the impact of the COVID-19 pandemic are a series of policies and or actions taken or not carried out by the Singkawang City Government with an orientation towards the goals of the vision and mission to solve public problems, mainly related to the prevention and control of COVID -19 and its impact, for the public interest in the tourism sector. The policy to restore or implement a new normal for tourism in Singkawang City is carried out by the government's provisions and regulations that it has a binding and coercive nature (Krisnawati, 2021).

The pandemic, which began in early March 2020, was surprising, especially in the tourism sector, which was previously acceptable. Workers and tourism business actors may still find it difficult to accept the reality of how they suddenly lost their jobs, stopped their business because of the pandemic that made people afraid, or was forbidden to travel before the social restrictions were introduced. Singkawang City, a tourist destination for West Kalimantan, was also affected by the COVID-19 social restrictions, which resulted in regional and community income from the tourism sector dropping drastically. Policy implementation activities in the form of organizing are an effort to determine and rearrange resources, units, and methods to make Singkawang City's tourism program face COVID-19 continue to run into results by what is expected. The goals and objectives of the policy.

All socialization of health protocols began to be encouraged by all provinces. Then to all trade sectors, tourism, all affected sectors, suddenly quieted down (Sigala, 2020; Le \& Phi, 2021). From April to July 2020, the tourism sector in Singkawang was quite hit by laying off employees or temporarily closing operations. Meanwhile, the budget for activities that have been planned is also withdrawn to the center so that activities cannot be carried out. The budget withdrawal is in line with the implementation of Presidential Instruction number 4 of 2020 issued by the President of the Republic of Indonesia, on March 22, 2020, regarding 
refocusing budget reallocation activities and the procurement of goods and services in accelerating the handling of COVID-19. There are no activities many times it changes; even tourism permits are temporarily suspended for four months (Castellani \& Sala, 2010; Uğur \& Akbıyık, 2020).

The tourism strategy in Singkawang City in principle follows the policy directions of the Central Government. However, in particular, the Singkawang City Tourism, Youth, and Sports Office have also designed several tourist event activities with the prerequisite that there are no social restrictions, such as in the early days of handling COVID-19. If crowds are allowed next year, then the strategy of events, competitions, competitions with attractive prizes on a regional scale can be carried out, of course, while still carrying out health protocols. The strategy, which is intended to attract the flow of tourist visits to Singkawang City, is planned to be packaged in 14 activities (not yet released because it is still a plan). Of the 14 events, routine agendas were carried out before the pandemic, such as the Cap Go Meh event, Ramadan Fair, Naik Danur, Putri Wisata; the rest was an innovation (tempo.co, 2021).

The Cap Go Meh Festival is an innovation event that brings in many local and foreign tourists. The presence of many tourists, tourists will stay, eat, and of course, are expected to re-excite tourism in Singkawang City. This strategy of targeting tourists from West Kalimantan Province is considered sufficient to inhabit hotels in Singkawang City, such as the long holiday period in August 2020. The plan for 14 events in West Kalimantan Province is connected to the carrying capacity of the Singkawang City destination ecosystem, which is quite complete, including beach, lake, mountain, cultural and artificial tourism. At the beginning of the adaptation period for new tourism habits due to the COVID-19 pandemic, conditions slowly improved, marked by visits and hotel rooms starting to fill. On weekends the hotel gets full but is still in the implementation of the recommended health protocol.

The condition that tends to lead to the recovery of Singkawang tourism is that the people around Pontianak, Mempawah City, Sambas City, and Bengkayang City are encouraged to travel. After all, they feel tired of being limited so far, maybe staying at home, children also not going to school. Possibly when the weekend is a holiday, for example, they will come to Singkawang. Including the possible influence of news from Singkawang City on negative rapid test results in traditional markets. So with the status of the green zone of Singkawang City (Abate et al., 2020; Díaz-Pérez et al., 2005).

The second policy implementation activity is interpretation, which is various efforts to explain the substance of Singkawang tourism policies in dealing with the impact of the COVID-19 pandemic. The efforts of the Singkawang City Tourism, Youth, and Sports Office to explain various policies, programs, activities, provisions, and or other information to the public and stakeholders. For this reason, interpretation activities should be conveyed and explained in a more functional and understandable language so that they can be implemented and accepted by the actors and policy targets or interpret so that the program becomes an appropriate plan and direction and can be accepted and implemented. Using social media such as Instagram and others is considered by the trends of the times and effectively targets the intended public. However, it is necessary to pay attention to the security and legal aspects of various means of communication so that the information is transparent, correct, and accountable (Fatkhudin, 2019; Aryee, 2020; Lee et al., 2019).

Several excerpts of statements or opinions from these participants indicate that the public can accept or understand the policies taken by the government in terms of economic recovery to overcome the impact of the COVID-19 pandemic on the Singkawang tourism sector. The interpretation of Singkawang's tourism policy in dealing with the impact of the COVID-19 pandemic is carried out managerially by abstracting general policies, strategic directions contained in-laws and regulations, presidential instructions, and those exposed to be managed in detailed and measurable managerial functions.

Managerial interpretation is followed up operationally on technical efforts in the field so that policy objectives can be accepted and implemented. Just like the policy of encouraging the flow of tourism to Singkawang through the jargon of "Surely to Singkawang" managerially, it has gone through several stages. However, it will be difficult for the public to understand if it is not operationalized into various media and channels such as social media and youtube. Websites with engaging content so that they can increase their subscribers.

The activity of providing services regularly for tourism in Singkawang City is by the objectives and means of existing policies. This study collects several facts and information needed to determine the application of tourism policy as a strategy to deal with the COVID-19 pandemic. Previously, at the beginning of the pandemic, Singkawang Mayor Tjhai Chui Mie had issued Singkawang City Mayor Regulation (Perwako)

Martoyo, M., Herlan, H., Sihaloho, N. T. P., \& Darmawan, D. (2021). Local government's response to the recovery of the tourism sector after the COVID-19 pandemic: case study in Singkawang City, Indonesia. International Journal of Social Sciences and Humanities, 5(3), 176-183. https://doi.org/10.53730/ijssh.v5n3.1580 
Number 17 of 2020 Social Restrictions on Activities in Public Places and Public Facilities in Prevention of Coronavirus Disease 2019 (COVID-19) in Singkawang City. This policy applies also received responses from the following participants:

1) The government has worked well because it always appeals to the community; only the people must be aware.

2) The Singkawang city government implements a "new normal," i.e., tourist attractions are reopened but must consistently implement physical distancing, use personal protective equipment, wear face shields, wear masks, provide hand sanitizers and lots of handwashing places, and provide body temperature checks before entering tourism places and provide sterilization booths.

3) The government should have new rules to maintain tourism in Singkawang in the current COVID pandemic.

4) Making rules according to strictly guarded protocols is not just an appeal, but tourist attractions are better managed so that the results can be utilized.

5) Continue to appeal to the public and tourism managers about the dangers of COVID-19 and how to overcome them.

6) Prepare all facilities and infrastructure to support health protocols and COVID-19 control.

7) Make strict rules for tourists when they want to visit Singkawang City.

Based on the results of an interview with the Mayor of Singkawang, it is known that the implementation of Singkawang City's tourism policy is generally also related to preventing the spread of COVID-19. There is also the factor of Presidential Instruction (INPRES) Number 4 of 2020 Refocusing Activities, Budget Reallocation, and Procurement of Goods and Services in the Context of Accelerating the Handling of COVID-19 is a temporary suspension of activities.

Annual routine program agendas and innovations during the new normal, with prerequisite conditions allowing crowds, implementation of plans to attract provincial-scale visits through competitions with prizes, implementation of cross-unit coordination, and application of managerial and operational interpretations using information technology, digital platforms, and other online applications, so that the public can well receive the substance of tourism policy information (Sharma et al., 2021; Qiu et al., 2020).

\section{Conclusion}

The efforts of the Singkawang City Government of Tourism, Youth and Sports in determining and rearranging tourism resources (natural, cultural, artificial) in provincial-scale event packages, coordination and cooperation across work units, methods of setting local tourism targets, attractions, tourism business empowerment, procedures, supervision, and technical implementation, but there is no visible creative effort based on health protocols in the implementation of tourism products.

The Singkawang City Government Tourism, Youth and Sports Office has carried out interpretation activities in the form of explaining the substance of tourism policies in more functional and easily understood language through social media (Instagram, Twitter, Youtube), whose intensity can be measured through trending topics indicators. Customers, followers so that it can be applied and accepted by the public. Actors and policy targets (netizens, followers, potential tourists, the public) and efforts to interpret tourism programs such as "Pasti Ke Singkawang" can be supported.

However, the implications for tourist visits have not been measured, and the anticipation of cyber security issues, hoax news, and the like. The efforts of the Singkawang City Tourism, Youth and Sports Office to apply the mitigation of the impact of COVID-19 based on central policies and Mayor Regulation 17/2020 related to preventing the spread of COVID-19, Mayor Regulation 37/2020, which regulates business activities during the new normal, but has not anticipated opportunities for new types of tourism that follow the trend of the pandemic by preparing alternative tours that do not involve many people. 
Acknowledgments

We are grateful to two anonymous reviewers for their valuable comments on the earlier version of this paper.

Martoyo, M., Herlan, H., Sihaloho, N. T. P., \& Darmawan, D. (2021). Local government's response to the recovery of the tourism sector after the COVID-19 pandemic: case study in Singkawang City, Indonesia. International Journal of Social Sciences and Humanities, 5(3), 176-183. https://doi.org/10.53730/ijssh.v5n3.1580 


\section{References}

Abate, M., Christidis, P., \& Purwanto, A. J. (2020). Government support to airlines in the aftermath of the COVID-19 pandemic. Journal of air transport management, 89, 101931. https://doi.org/10.1016/j.jairtraman.2020.101931

Amerta, I. M. S., Sara, I. M., \& Bagiada, K. (2018). Sustainable tourism development. International research journal of management, IT and social sciences, 5(2), 248-254.

Aryee, D. (2020). Cybersecurity Threats to the Hotel Industry and Mitigation Strategies (Doctoral dissertation, Utica College).

Castellani, V., \& Sala, S. (2010). Sustainable performance index for tourism policy development. Tourism management, 31(6), 871-880. https://doi.org/10.1016/j.tourman.2009.10.001

Chandler, R. C. (1982). The public administration dictionary. John Wiley \& Sons.

Díaz-Pérez, F. M., Bethencourt-Cejas, M., \& Álvarez-González, J. A. (2005). The segmentation of canary island tourism markets by expenditure: implications for tourism policy. Tourism Management, 26(6), 961-964. https://doi.org/10.1016/j.tourman.2004.06.009

Easton, D. (1979). A Systems Analysis of Political Life. Chicago: U.

Fatkhudin, A. (2019). Sistem Informasi Geografis Wisata Gunung Di Pekalongan Berbasis Android. Jurnal Ilmiah Ilmu Komputer Fakultas Ilmu Komputer Universitas Al Asyariah Mandar, 5(1), 13-18.

González-Torres, T., Rodríguez-Sánchez, J. L., \& Pelechano-Barahona, E. (2021). Managing relationships in the Tourism Supply Chain to overcome epidemic outbreaks: The case of COVID-19 and the hospitality industry in Spain. International journal of hospitality management, 92, 102733. https://doi.org/10.1016/j.ijhm.2020.102733

Haque, Z. (2015). The impact of economic crisis on tourism industry. International Research Journal of Engineering, IT and Scientific Research, 1(1), 12-23.

Krisnawati, N. (2021). Strategic Approaches For Mitigating Crisis In Village Tourist Destination Sector In West Kalimantan. Journal of Tourism Destination and Attraction, 9(1), 11-26.

Le, D., \& Phi, G. (2021). Strategic responses of the hotel sector to COVID-19: Toward a refined pandemic crisis management framework. International Journal of Hospitality Management, 94, 102808. https://doi.org/10.1016/j.ijhm.2020.102808

Lee, S., Jeon, S., \& Lee, B. (2019). Security controls for employees' satisfaction: perspective of controls framework. SAGE Open, 9(2), 2158244019853908.

Qiu, R. T., Park, J., Li, S., \& Song, H. (2020). Social costs of tourism during the COVID-19 pandemic. Annals of Tourism Research, 84, 102994. https://doi.org/10.1016/j.annals.2020.102994

Sharma, G. D., Thomas, A., \& Paul, J. (2021). Reviving tourism industry post-COVID-19: A resilience-based framework. Tourism management perspectives, 37, 100786. https://doi.org/10.1016/j.tmp.2020.100786

Sigala, M. (2020). Tourism and COVID-19: Impacts and implications for advancing and resetting industry and research. Journal of business research, 117, 312-321. https://doi.org/10.1016/j.jbusres.2020.06.015

Škare, M., Soriano, D. R., \& Porada-Rochoń, M. (2021). Impact of COVID-19 on the travel and tourism industry. Technological Forecasting and Social Change, 163, 120469. https://doi.org/10.1016/j.techfore.2020.120469

Sugiyono, P. (2015). Metode penelitian kombinasi (mixed methods). Bandung: Alfabeta, 28, 1-12.

Uğur, N. G., \& Akbiyık, A. (2020). Impacts of COVID-19 on global tourism industry: A cross-regional comparison. Tourism Management Perspectives, 36, 100744. https://doi.org/10.1016/j.tmp.2020.100744

Woll, P. (2002). Public Policy. Massachusetts: Winthrop Publishers. 


\section{Biography of Authors}

\begin{tabular}{l|l||} 
Dr. H. Martoyo, M.A. Doctor of Public Administration and Dean of the Faculty of \\
Social and Political Sciences, University of Tanjungpura. \\
Email: martoyo@fisip.untan.ac.id
\end{tabular}

Martoyo, M., Herlan, H., Sihaloho, N. T. P., \& Darmawan, D. (2021). Local government's response to the recovery of the tourism sector after the COVID-19 pandemic: case study in Singkawang City, Indonesia. International Journal of Social Sciences and Humanities, 5(3), 176-183. https://doi.org/10.53730/ijssh.v5n3.1580 